\title{
ERGONOMIC AND PERSONAL PROTECTION EQUIPMENT (PPE) IMPLEMENTATION IN PT MACANAN JAYA CEMERLANG
}

\section{PENERAPAN ERGONOMI DAN ALAT PELINDUNG DIRI (APD) DI PT MACANAN JAYA CEMERLANG}

\author{
Fikri Alkndi ${ }^{\mathrm{a}^{*}}$, MT Djamara ${ }^{\mathrm{a}}$, Abdul Majid ${ }^{\mathrm{a}}$ \\ a Teknik Grafika, Politeknik Negeri Media Kreatif, Indonesia \\ *Email: fiqri0203@gmail.com
}

\begin{abstract}
Occupational Health and Safety is one of the important factors in supporting the smooth production process. Therefore all workers and other people who are in the workplace must understand and actively participate in all activities that have an insight into occupational safety and health at PT. Macanan Jaya Cemerlang, and must always use Personal Protective Equipment (PPE) while in the company environment. Ergonomics and $K 3$ are two inseparable things, both of which lead to the same goal of improving the quality of life of workers. Ergonomics is a science and its application that seeks to harmonize work and the environment for people or vice versa with the aim of achieving the highest productivity and efficiency through optimal human use. PT. Macanan Jaya Cemerlang as one of the major graphic companies in Indonesia, needs to implement good work ergonomics, to maintain employee productivity and work efficiency, and to improve physical and mental well-being through efforts to prevent injuries and occupational diseases (PAK). This thesis aims to determine whether the application of work ergonomics is related to safety and health in PT. Macanan Jaya Cemerlang whether it has been implemented properly.
\end{abstract}

Keywords: OHS, Ergonomy and Printing Industry

\begin{abstract}
Abstrak-Keselamatan dan Kesehatan Kerja (K3) adalah salah satu faktor penting dalam menunjang kelancaran proses produksi. Oleh karena itu semua pekerja maupun orang lain yang berada ditempat kerja harus memahami dan aktif ikut serta dalam segala kegiatan yang berwawasan tentang keselamatan dan kesehatan kerja di PT. Macanan Jaya Cemerlang, serta harus selalu menggunakan Alat Pelindung Diri (APD) selama berada dilingkungan perusahaan.
\end{abstract}


Ergonomi dan K3 merupakan dua hal yang tidak dapat dipisahkan, keduanya mengarah kepada tujuan yang sama yakni peningkatan kualitas kehidupan pekerja. Ergonomi adalah ilmu serta penerapannya yang berusaha menyerasikan pekerjaan dan lingkungan terhadap orang atau sebaliknya dengan tujuan tercapainya produktivitas dan efisiensi yang setinggi-tingginya melalui pemanfaatan manusia seoptimal mungkin. Penulisan ini bertujuan untuk mengetahui apakah penerapan ergonomi kerja yang berkatian dengan keselamatan dan kesehatan di PT. Macanan Jaya Cemerlang. PT. Macanan Jaya Cemerlang sebagai salah satu perusahaan besar grafika yang ada di Indonesia, perlu menerapkan ergonomi kerja dengan baik, agar terjaganya produktivitas dan efisiensi kerja karyawan, serta meningkatkan kesejahteraan fisik dan mental melalui upaya pencegahan cedera dan Penyakit Akibat Kerja (PAK).

\section{Kata Kunci: Ergonomi, K3 dan Industri Grafika}

\section{PENDAHULUAN}

Bangsa Indonesia merupakan salah satu Negara yang memiliki jumlah penduduk terbanyak di dunia setelah Tiongkok, India, dan Amerika Serikat yakni dengan jumlah kurang lebih 255 juta jiwa. Untuk melangsungkan kehidupannya para penduduk tersebut membutuhkan pekerjaan. Sehubungan dengan itu pembangunan ketenaga kerjaan diarahkan pada pembentukan dan peningkatan tenaga professional yang mandiri, beretos kerja tinggi, berkualitas, produktif, efisiensi, berdaya saing tinggi, dan jujur.

Dalam melakukan pekerjaannya pekerja itu ditunut untuk selalu berhati-hati, di samping itu pekerja juga mendapat pengawasan tentang keselamatan kerja dari perusahaan. Sesuai dengan ketentuan dalam Undang-Undang No. 13 tahun 2003 tentang ketenagakerjaan, yang menyebutkan bahwa setiap perusahaan wajib melaksanakan upaya Keselamatan dan Kesehatan Kerja (K3) untuk melindungi keselamatan para pekerja dan sarana produksi yang digunakan di area kerja. Dimana dalam perkembangan ilmu pengetahuan dan teknologi telah membuat dunia industri berlomba-lomba melakukan efisiensi dan meningkatkan dengan menggunakan alat-alat produksi yang semakin komplek. Makin kompleknya peralatan yang digunakan makin besar pula risiko kecelakaan kerja yang ditimbulkan apabila tidak dilakukan penanganan dan pengendalian K3 dengan sebaik-baiknya.

Istilah ergonomi berasal dari Istilah ergonomi berasal dari bahasa Yunani yang terdiri dua kata yaitu "ergon" berarti kerja dan "nomos" berarti aturan atau hukum. Jadi secara ringkas ergonomi adalah suatu aturan 
atau norma dalam sistem kerja. Di Indonesia memakai istilah ergonomi, tetapi di beberapa negara seperti di Skandinavia menggunakan istilah "Bioteknologi" sedangkan di negara Amerika menggunakan istilah "Human Engineering" atau "Human Factors Engineering".

Namun demikian, kesemuanya membahas hal yang sama yaitu tentang optimalisasi fungsi manusia terhadap aktivitas yang dilakukan. Ergonomi yaitu ilmu yang mempelajari perilaku manusia dalam kaitannya dengan pekerjaan mereka.

Sasaran penelitian ergonomic adalah manusia pada saat bekerja dalam lingkungan peerjaan. Secara singkat dapat dikatakan bahwa ergonomic ialah penyesuaian tugas pekerjaan dengan kondisi tubuh manusia untuk menurunkan stres yang akan dihadapi. Upayanya antara lain beruupa menyesuaikan ukuran tempat kerja dengan dimensi tubuh agar tidak melelahkan, mengatur kebisingan, pengaturan suhu, cahaya atau penerangan, dan kelembaban yang bertujuan agar sesuai dengan kebutuhan tubuh manusia di tempat kerja (Departemen Kesehatan RI, 2007). Setiap aktivitas atau pekerjaan yang dilakukan, apabila tidak dilakukan secara ergonomis akan mengakibatkan ketidaknyamanan, biaya tinggi, kecelakaan dan penyakit akibat kerja meningkat, performansi menurun yang berakibat kepada penurunan efisiensi dan daya kerja. Dengan demikian, penerapan ergonomi di segala bidang kegiatan adalah suatu keharusan.

\section{Ergonomi memiliki beberapa tujuan yang ingin dicapai, diantaranya :}

1. Meningkatkan kesejahteraan fisik dan mental melalui upaya pencegahan cedera dan penyakit akibat kerja, menurunan beban kerja fisik dan mental, mengupayakan promosi, dan kepuasan kerja.

2. Meningkatkan kesejahteraan social melalui peningkatan kualitas kontak social dan mengkoordinasi kerja secara cepat, guna meningkatkan jaminan social baik selama kurun waktu usia produktif maupun setelah tidak produktif.

3. Menciptakan keseimbangan rasional antara aspek teknis, ekonomis, dan antropologis dari setiap sistem kerja yang dilakukan sehingga tercipta kualitas kerja dan kualitas hidup yang tinggi.

Ergonomi dapat diterapkan pada beberapa aspek dalam bekerja. Penerapan aspek tersebut antara lain.

\section{Posisi kerja}

Terdiri dari posisi duduk dan posisi berdiri. Posisi duduk dimana kaki tidak terbebani dengan berat tubuh dan posisi stabil selama bekerja, sedangkan posisi berdiri dimana posisi tulang belakang vertical dan 
berat badan tertumpu secara seimbang pada dua kaki.

\section{Proses kerja}

Para pekerja dapat menjangkau peralatan kerja sesuai dengan posisi waktu bekerja agar mempermudah dalam proses kerja.

\section{Tata letak tempat kerja (display)}

Display harus jelas terlihat pada waktu melakukan aktivitas kerja. Sedangkan symbol yang jelas dan mudah dipahami harus lebih banyak digunakan dari pada kata-kata

\section{Mengangkat beban}

Bermacam-macam cara dalam mengangkat beban yaitu dengan kepala, bahu, tangan, punggung, dan sebagainya. Beban yang terlalu berat dapat menimbulkan cedera tulang punggung, jaringan otot, dan persendian akibat gerakan yang berlebihan.

Ergonomi dan K3 merupakan dua hal yang tidak dapat dipisahkan. Keduanya mengaarh epada tujuan yang sama yakni peningkatan kualitas kehidupan kerja. Oleh karena itu, penulis memiliki ketertarikan untuk membahas tentang “ PENERAPAN ERGONOMI KERJA DI PT.MACANAN JAYA CEMERLANG”.

Berdasarkan dengan judul yang penulis ambil maka dapat dirumuskan kedalam bentuk pertanyaan sebagai berikut:
1. Bagaimana gambaran perusahaan tersebut;

2. Bagaimana penerapan Ergonomic kerja PT.Macanan Jaya Cemerlang dan

3. Apa saja kekurangan yang ada dalam penerapan Ergonomi kerja dan bagaimana mengatasinya

4. Bagaimana penerapan APD di Industri tersebut.

Tujuan Penulisan dalam penelitian ini adalah Untuk mengetahui gambaran perusahaan tersebut, untuk mengetahui penerapan Ergonomi kerja di PT.Macanan Jaya Cemerlang dan Untuk mengetahui kekurangan yang terjadi dalam penerapan Ergonomi kerja di PT.Macanan Jaya Cemerlang dan bagaimana cara mengatasi kekurangan tersebut.

\section{Manfaat Penulisan}

\section{Bagi perusahaan}

1. Dapat memberikan informasi tentang pembelajaran mengenai Keselamatan dan Kesehatan Kerj (K3).

2. Dapat memberikan masukan yang berarti bagi perusahaan dan dapat digunakan sebagai bahan evaluasi, khususnya mengenai “ Penerapan Ergonomi Kerja Yang Berkaitan Dengan Keselamatan Dan Kesehatan Kerja Di PT.Macanan Jaya Cemerlang"

Bagi Politeknik Negeri Media Kreatif Jakarta 
1. Mendapatkan informasi tentang

Penulis menggunakan beberapa perkembangan industry diluar, khususnya pada PT.Macanan Jaya Cemerlang

2. Untuk menambah kepustakaan atau referensi tentang Keselamatan dan Kesehatan Kerja (K3), khususnya mengenai penerapan Ergonomi Kerja di PT. Macanan Jaya Cemerlang

\section{Bagi penulis}

1. Untuk mengetahui penerapan dan manfaat Keselamatan dan Kesehatan Kerja (K3) di industri, juga untu mengetahui cara mencegah, mengurangi, bahkan menghilangkan risiko kecelakaan kerja (zero accident) di area kerja, dan untuk mengetahui penerapan Ergonomi kerja di PT.Macanan Jaya Cemerlang

\section{Manfaat Secara Teori}

1. Mengetahui bagaiamana penerapan ergonomi kerja di PT. Macananjaya Cemerlang.

2. Mengetahui apa saja kekurangan yang ada dalam penerapan ergonomi kerja di PT. Macananjaya Cemerlang.

\section{Manfaat Secara Praktik}

1. Mengidentifikasi bagaimana penerapan ergonomi yang benar.

2. Mengidentifikasi kekurangan dalam penerapan ergonomic kerja dan mengetahui solusinya.

\section{METODE PENELITIAN}

Metode Pengumpulan Data

metode untuk pengumpulan data dalam pembuatan Tugas Akhir ini. Hal ini bertujuan untuk memperoleh informasi yang lebih akurat dalam melengkapi data serta memperoleh solusi yang baik untuk memecahkan masalah yang ada dalam pembahasan Tugas Akhir ini. Metode yang digunakan adalah :

\section{Metode observasi}

Penulis melakukan observasi atau pengamatan langsung dilapangan yaitu pada bagian cetak PT.Macanan Jaya Cemerlang sesuai dengan judul yang penulis angkat.

\section{Metode wawancara}

Penulis melakukan wawancara dengan pihak-pihak yang berhubungan dengan objek penelitian untuk memperoleh penjelasan mengenai data yang benar, serta mendapatkan solusi terbaik dari setiap permasalahan yang timbul pada penerapan sistem Keselamatan dan Kesehatan Kerja (K3) pada bagian cetak di PT. Macanan Jaya Kerja.

\section{Metode kepustakaan}

Penulis mencari dan mengumpulkan data yang diperlukan dari bahan-bahan referensi seperti buku-buku, internet, laporan magang, laporan Tugas Akhir tentang Keselamatan dan Kesehatan Kerja (K3), artikel-artikel, dan materi kuliah yang bersangkutan dengan judul yang penulis 
angkat.

\section{HASIL DAN PEMBAHASAN}

\section{Gambaran Perusahaan}

\section{Sejarah Singkat Perusahaan}

PT Macananjaya Cemerlang adalah perusahaan penerbit dan percetakan yang berlokasi di jalan KI Hajar Dewantoro, Klaten Utara dengan Akte pendirian perseroan terbatas No.72 tanggal 25 Oktober 1991, menempati area seluas $48.252 \mathrm{~m} 2$ dengan luas banguan $14.231 \mathrm{~m} 2$. Sejak tahun 1992 PT Macananjaya Cemerlang telah mendapatkan kepercayaan dalam pengerjaan berbagai proyek dan pengadaan buku sekolah berskala nasional dan internasional.

Tahun 1998, PT Macananjaya Cemerlang telah mampu mengembangkan usaha ke pencetakan kemasan beberapa clien besar di indonesia di bidang makanan dan minuman. Selanjutnya tahun 2003, banyak dipercaya dan memenangkan proyek cetak dari berbagai instansi pemerintah tingkat pusat maupun daerah. Sebut saja, pencetakan surat suara untuk pemilu di tahun 2004,2009,2014, baik pemilihan legislatif, pemilihan presiden, pilkada jawa timur dan beberapa daerah kota maupun provinsi. Pencetakan formulir di beberapa wilayah direktorat jenderal pajak, dan sebagainya.

Di dukung lebih dari 1000 orang Sumber Daya Manusia profesional yang bekerja dengan Sistem Manajemen yang terintegrasi (Mutu, Lingkungan, dan Keselamatan \& Kesehatan Kerja) PT Macananjaya Cemerlang siap menjawab tantangan yang ada. Harga yang menarik, Ketepatan Waktu dan Kuakitas merupakan jaminan keunggulan kami dan kepuasan semua pihak adalah tujuan bersama.

Visi Dan Misi PT. Macananjaya Cemerlang PT. Macananjaya Cemerlang memiliki visi dan misi untuk menunjang semua pekerjaan dan target pencapaian perusahaan, diantaranya Menjadi perusahaan percetakan multinasional dan mandiri adapun misinya adalah, antara lain:

Meningkatkan fasilitas produksi, kualitas sumber daya manusia dan organisasi secara berkesinambungan dan Meningkatkan segmentasi pasar, diverivikasi produk, dan ekstensifikasi.

\section{Lokasi Dan Tata Letak Perusahaan}

Letak perusahaan adalah tempat dimana perusahaan menjalankan operasional proses bisnis dan segala kegiatannya. Pemilihan lokasi sangatlah penting, hal ini karena dapat menunjang usaha dan kelangsungan hidup perusahaan.

\section{Struktur Organisasi}

Struktur organisasi adalah bagaimana pekerjaan dibagi, dikelompokkan, dan dikoordinasikan secara formal. Fungsi dari struktur organisasi sendiri adalah:

1. Memberikan kejelasan tanggung jawab, maksudnya setiap anggota dari organisasi 
harus dapat brtanggung jawab dan apasaja yang harus dia pertanggungjawabkan.

2. Memberikan kejelasan kedudukan, dengan arti anggota atau seseorang yang ada dalam struktur organisasi dapat mempermudah dalam koordinasi dan hubungan, sebab adanya keterkaitan penyelesaian mengenai suatu fungsi yang telah dipercayakan.

3. Memberikan kejelasan mengenai jalur hubungan, maksudnya dengan terbentuk struktur organisasi maka jalur hubungan untuk penyelesaian suatu pekerjaan akan lebih terkoordinir dan efektif serta memberikan keuntungan.

4. Memberikan kejelasan uraian tugas terhadap seseorang sesuai dengan bagianbagiannya.

\section{Job Deskripsi}

Didalam struktur organisasi terdiri dari bagian-bagian tertentu yang setiap bagian-bagiannya memiliki tugas dan tanggung jawab yang berbeda-beda sesuai dengan posisi yang di tempatinya. Berikut ini adalah pembagian tugas dan tanggung jawab di setiap bagian yang ada dalam struktur organisasi yang ada di PT. Macananjaya Cemerlang.

\section{Direktur}

1. Menjalankan perusahaan sesuai dengan perencanaan yang telah ditetapkan oleh perusahaan.
2. Membantu perencanaan kegiatan operasional perusahaan dalam rangka mengembangkan perusahaan dan menjamin perusahaan untuk tetap berjalan sesuai tujuan perusahaan.

3. Membina hubungan baik dengan pihakpihak yang bekerja sama dengan perusahaan.

\section{Kepala Bagian PPIC}

1. Mengelola semua oreder cetak dari pemasaran untuk di program sesuai urutan order dan skala prioritas.

2. Menerima dan menganalisa PO. SPO internal memo sebagai dasar penyusunan program kerja cetak.

3. Memastikan urutan program kerja cetak sesuai dengan hasil meeting program

4. Memonitorealisasi program kerja cetak dan menganalisa penyimpanan produksi terhadap program kerja cetak

\section{Kepala Urusan Personalia Percetakan}

1. Berkoordinasi dengan bagian personalia divisi penerbit dan bagian lainnya mengenai perencanaan kebutuhan SDM dengan memperhatikan kebutuhan operasional perusahaan.

2. Melakukan monitoring data mengenai perencanaan kebutuhan SDM untuk keperluan pemenuhan tenaga kerja.

3. Merencanakan proses pemenuhan kebutuhan SDM baik melalui proses 
rekrutmen karyawan baru atau usulan

untuk mutasi dan promosi karyawan.

\section{Kepala Urusan Gudang Logistik}

\section{Percetakan}

1. Menerima, memeriksa dan melakukan sampling penerimaan untuk setiap barang yang diterima dari supplier.

2. Melakukan pencatatan penerimaan dan pengeluaran atas bahan baku kertas, bahan baku pembantu dan sparepart mesin.

3. Mengisi rekap setiap harinya mengenai penerimaan dan pengeluarankertas, bahanbaku pembantu dan sparepart mesin

\section{Kepala Bagian Cetak}

1. Memastikan kelancaran produksi pada bagian cetak.

2. Memastikan jalannya suatu aturan/kebijakan yang berlaku di bagian cetak.

3. Mengatur pembagian kerja dan personil bagian cetak.

4. Memberikan bimbingan serta saran terhadap suatu masalah yang di alami karyawan cetak.

\section{Administrasi Produksi}

1. Membuat laporan pemakaian kertas roll untuk setiap SPO.

2. Membuat pantauan serta menyajikan laporan monitor kerja mesin.
3. Melaporkan setiap kejadian terkait dengan kesehatan dan keselamatan kerja.

\section{Operator Cetak}

1. Melakukan proses cetak sesuai dengan order kerja percetakan.

2. Melakukan pengecekan terhadap jumlah, jenis, serta kualitas bahan cetak yang diterima dari pengorder sesuai dengan intruksi kerja mesin cetak.

3. Melakukan proses cetak sesuai dengan intruksi kerja.

\section{Kepala Bagian Produksi Pra Cetak}

Merupakan Unit produksi yang sedianya mengolah materi order dari pemesan menjadi materi yang siap untuk dicetak. Adapun tugas - tugas dari unit produksi pra cetak ini, yaitu:

- Menerima SPK ( surat perintah kerja ) dari bagian perencanaan percetakan

- Layout

- Setting

- Retouching

- Imagesetter

- Mounting

- Membuat proof / blue print

- Plate making.

\section{Petugas Pengorder Cetak}

1. Menulis order kerja percetakan untuk semua mesin berdasarkan program kerja yang telah diberikan oleh bagian PPIC. 
Melakukan serah terima plat dari bagian pra cetak untuk plat yan akan naik cetak.

2. Membuat urutan prioritas order per mesin berdasarkan program kerja

\section{Kepala Bagian Produksi Finishing}

Pada unit produksi ini hasil cetakan di ubah kedalam bentuk akhir atau bentuk menjadi berupa buku, majalah, tabloid, dll. Tugas unit finishing antara lain :

1. Menerima SPK (surat perintah kerja) dari bagian perencanaan percetakan

2. Menerima bahan yang akan digunakan

3. Proses finishing (pelipatan, pengkomplitan, jahit kawat, jahit benang, lem panas, lem vernish, dan pemotongan bersih buku atau majalah 3 sisi)

4. ACC hasil penjilidan

5. Sortir kualitas hasil finishing

6. Packing / pengepakan buku.

\section{Bidang Usaha dan Produk Perusahaan}

Bidang usaha

PT.Macananjaya Cemerlang adalah Perusahaan yang bergerak dalam bidang percetakan offset dan penerbit. Berbagai macam cetak offset dikelompokkan sebagai berikut:

- Al-qur'an terjemah

- majalah

- buku

\section{Ketenagakerjaan}

Jumlah karyawan percetakan di PT. Macananjaya Cemerlang berjumlah 1000 orang Sumber Daya Manusia Profesiaonal yang bekerja dengan sistem managemen yang terintegrasi, dengan bagian yang berbedabeda

\section{Kebijakan QHSE (Quality Health Safety and Enviontment) / Bagian K3.}

Meningkatkan mutu produk dan ketepatan waktu penyelesaian order untuk kepuasan pelanggan dengan melakukan perbaikan terus menerus serta menjaga kesehatan, keselamatan dan perduli terhadap lingkungan.

- Berkomitmen untuk mentaati peraturan perundang-undangan yang berlaku dan persyaratan lain yang terkait dengan aspek lingkungan dan bahaya kesehatan dan keselamatan kerja.

- Berkomitmen untuk mencegah pencemaran lingkungan.

- Berkomitmen untuk melakukan pencegahan cedera dan sakit yang ditimbulkan akibat kerja

- Berkomitmen untuk perbaikan berkelanjutan terkait dengan sistem manajemen QHSE.

\section{Tinjauan Praktik Industri}

\section{Bagian Pra Cetak}

Kegiatan pada proses pra cetak adalah desain, dan pembuatan plat cetak, di bagian pra cetak hanya ada 1 shift, dan tidak ada yang lembur. Kondisi ruangan pra cetak di PT. Macanan Jaya Cemerlang cukup terjaga 
kerapihan dan kebersihannya, kesadaran karyawan dalam menggunakan APD juga cukup baik, dan kinerja karyawan di pra cetak juga baik. Sebelum memulai kegiatan seluruh karyawan melakukan kegiatan bersih-bersih lingkungan kerja dan mesin. APD yang digunakan di Pra Cetak adalah masker, sarung tangan, dan sarung tangan anti panas. Di bagian pra cetak tidak ada ToolKit

Masalah yang sering ada di pra cetak adalah aroma menyengat dari bahan-bahan kimia yang ada, kesadaran karyawan dalam penggunaan APD, masih adanya beberapa karyawan yang kurang kesadarannya dalam menggunakan APD walaupun hanya masker dan sarung tangan. Dan karena sedang adanya pembangunan ruangan baru di Pra Cetak untuk penempatan mesin baru, kegiatan di Pra Cetak sedikit terganggu.

\section{Bagian Cetak}

Proses cetak merupakan proses pengalihan tinta cetak dari acuan ke bahan cetak dengan menggunakan tekanan dan kecepatan tertentu. Proses cetak berfungsi untuk menggadakan sekumpulan gambar atau teks sesuai dengan acuan cetak atau plate yang dibuat dibagian pra cetak. Di bagian cetak terdiri dari 2 shift, da nada lemburnya. Kondisi ruangan cetak di PT. Macanan Jaya Cemerlang terlihat rapih dan bersih, karena setiap hari sebelum dan seudah melakukan kegiatan produksi selalu ada kegiatan bersihbersih lingkungan kerja dan mesin. Kinerja karyawan dibagian cetak cukup baik. Apd yang digunakan pada proses cetak adalah masker, sarung tangan, safety shoes, dan ear plug untuk dibagian cetak web.

\section{Masalah yang sering terjadi di bagian cetak :}

Masih adanya beberapa karyawan yang tidak menggunakan APD lengkap.

- Tidak adanya perawatan meesin secara berkala.

- Kurang memperhatikan tata letak manajemen 5R.

- Kurangnya mengoptimalkan penggunaan toolkit.

- Jam lembur yang tidak menentu dan diwajibkan.

- Kurangnya kotak P3K.

\section{Bagian Pasca Cetak}

Pada bagian ini hasil cetakan akan diaplikasikan sesuai dengan kebutuhan. Ada beberapa jenis atau tahapan pasca cetak yang umum dilakukan dalam penyelesaian

Di bagian pasca cetak ada 2 shift dan ada lemburnya. Kondisi ruangan pasca cetak di PT. Macanan Jaya Cemerlang cukup terlihat rapih dan bersih, setiap karyawan setiap harinya melakukan bersih-bersih lingkungan kerja dan mesin sebelum memulai pekerjaan. Kinerja karyawan dibagian pasca cetak cukup baik, namun masih ada beberapa kurang baik. Dan kesadaran dalam menggunakan APD pun cukup baik, APD yang digunakan di pasca cetak adalah masker, 
safety shoes, sarung tangan, dan sarung tangan anti panas.

Masalah yang sering terjadi di

\section{bagian pasca cetak :}

- Masih adanya beberapa karyawan yang tidak menggunakan APD lengkap.

- Tidak adanya perawatan meesin secara berkala.

- Kurang memperhatikan tata letak manajemen 5R.

- Jam lembur yang tidak menentu dan diwajibkan.

- Kurangnya kotak P3K.

- Kurang lengkapnya alat bantu dibagian sortir

\section{Penerapan Ergonomi di PT Macanan Jaya}

\section{Cemerlang}

\section{Bagian Pra Cetak}

Penerapan ergonomi kerja dibagian Pra Cetak sudah diterapkan dengan baik, hal itu di lihat dari kinerja karyawan yang efisien, kesadaran dalam penggunaan Alat Pelindung Diri (APD) sudah cukup baik, mematuhi segala peraturan yang ada, dan tidak adanya karyawan yang bercanda dan bermalas-malasan dalam bekerja.

Kebersihan di ruangan Pra Cetak selalu terjaga demi kenyamanan karyawan dalam bekerja, dan setiap hari sabtu karyawan Pra Cetak mengikuti olahraga jalan sehat dan senam, dan setelah melakukan olahraga karyawan mendapatkan susu murni, agar kesehatan dan kebugaran karyawan tetap terjaga, kotak $\mathrm{P} 3 \mathrm{~K}$ tersedia di ruangan pra cetak, agar apa bila ada karyawan yang hanya terluka ringan bisa diobati ditempat tidak perlu ke poliklinik agar tidak membuang waktu. Di bagian pra cetak tidak ada toolkit untuk meletakan alat bantu.

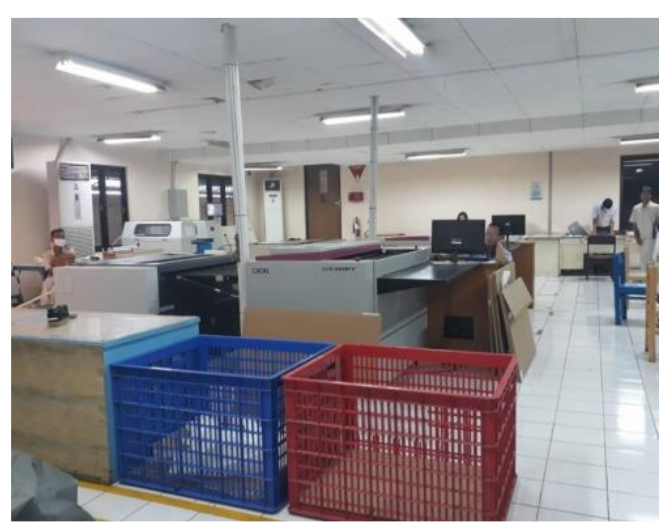

Gambar 1. Ruangan Pra cetak

\section{Penerapan Ergonomi Kerja di bagian Cetak}

Penerapan ergonomi kerja dibagian Cetak Sheet \& Web sudah diterapkan dengan baik, hal itu di lihat dari kinerja karyawan yang efisien, kesadaran dalam penggunaan Alat Pelindung Diri (APD) sudah cukup baik, mematuhi segala peraturan yang ada, dan tidak adanya karyawan yang bercanda dan bermalasmalasan dalam bekerja.

Kebersihan di ruangan Cetak Sheet \& Web selalu terjaga demi kenyamanan karyawan dalam bekerja, setiap hari ada bersih-bersih tempat kerja dan mesin sebelum melakukan kegiatan, dan setiap hari sabtu karyawan Cetak sheet \& web mengikuti olahraga jalan sehat dan senam, dan setelah melakukan olahraga karyawan mendapatkan susu murni, agar kesehatan dan kebugaran karyawan tetap 
terjaga, kotak P3K tersedia di ruangan cetak sheet \& web, agar apa bila ada karyawan yang hanya terluka ringan bisa diobati ditempat tidak perlu ke poliklinik agar tidak membuang waktu. Di bagian cetak sheet dan cetak web memiliki toolkit, dibagian cetak sheet setiap mesin memiliki toolkit tersendiri, di bagian cetak web toolkitnya lebih besar kapasitasnya.

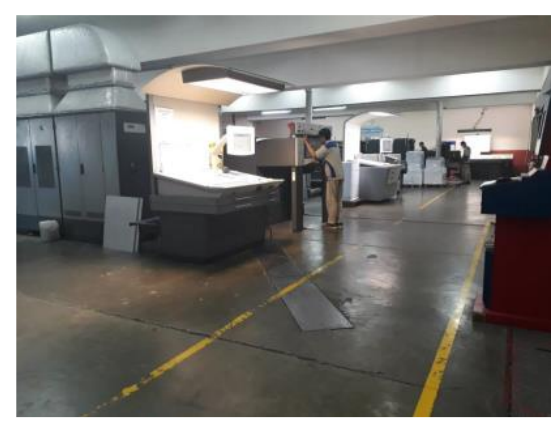

Gambar 2. Ruangan Cetak (Offset)

Penerapan Ergonomi Kerja di bagian Pasca Cetak

Penerapan ergonomi kerja dibagian Pasca Cetak sudah diterapkan dengan baik, hal itu di lihat dari kinerja karyawan yang efisien, kesadaran dalam penggunaan Alat Pelindung Diri (APD) sudah cukup baik, mematuhi segala peraturan yang ada, dan tidak adanya karyawan yang bercanda dan bermalas-malasan dalam bekerja.

Kebersihan di ruangan Pasca Cetak selalu terjaga demi kenyamanan karyawan dalam bekerja, setiap hari ada bersih-bersih tempat kerja dan mesin sebelum melakukan kegiatan, dan setiap hari sabtu karyawan Pasca Cetak mengikuti olahraga jalan sehat dan senam, dan setelah melakukan olahraga karyawan mendapatkan susu murni, agar kesehatan dan kebugaran karyawan tetap terjaga, kotak P3K tersedia di ruangan pasca cetak, agar apa bila ada karyawan yang hanya terluka ringan bisa diobati ditempat tidak perlu ke poliklinik agar tidak membuang waktu.

Di bagian pasca cetak setiap mesin memiliki toolkit tersendiri. Karena dibagian pasca cetak memiliki banyak mesin, dan setiap mesin berbeda alat bantunya.

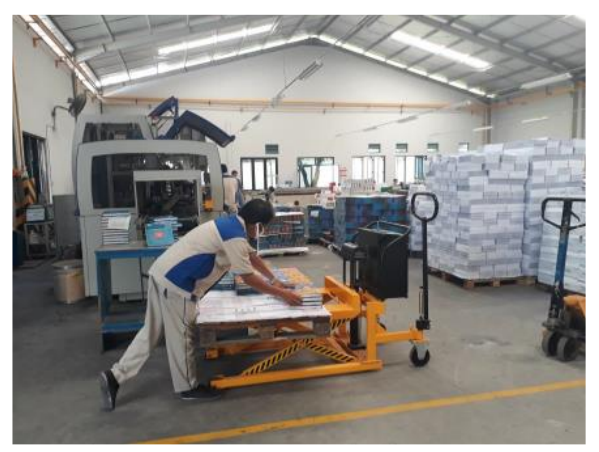

Gambar 3. Ruangan Pasca Cetak

\section{Posisi Kerja di Bagian Sortir}

Menurut pengamatan penulis, penerapan ergonomic dalam posisi kerja dibagian sortir atau pengemasan kurang diperhatikan oleh pihak perusahaan hal itu dilihat dari fasilitas tempat duduk yang kurang nyaman karena terbuat dari bahan yang keras (kayu) yang bisa mengakibatkan karyawan cepat merasakan pegal, dan juga fasilitas meja yang kurang luas mengakibatkan kurang leluasanya pergerakan karyawan dalam melakukan pekerjaannya dan juga ditambah lagi ada banyak tumpukan hasil produksi yang sudah disortir.

Dan dibagian sortir masih ada yang bekerja tanpa menggunakan meja dan kursi atau bekerja dibawah, hal ini bisa membuat karyawan sakit pinggang karena posisi kerja yang tidak benar, dan juga bisa membuat tubuh 
karyawan menjadi bungkuk apa bila terlalu sering kerja dibawah tanpa menggunakan kursi dan meja.

Upayanya antara lain beruupa menyesuaikan ukuran tempat kerja dengan dimensi tubuh agar tidak melelahkan, mengatur kebisingan, pengaturan suhu, cahaya atau penerangan, dan kelembaban yang bertujuan agar sesuai dengan kebutuhan tubuh manusia di tempat kerja (Departemen Kesehatan RI, 2007). Setiap aktivitas atau pekerjaan yang dilakukan, apabila tidak dilakukan secara ergonomis akan mengakibatkan ketidaknyamanan, biaya tinggi, kecelakaan dan penyakit akibat kerja meningkat, performansi menurun yang berakibat kepada penurunan efisiensi dan daya kerja. Dengan demikian, penerapan ergonomi di segala bidang kegiatan adalah suatu keharusan.

\section{Kekurangan Dalam Penerapan Ergonomi}

\section{Kerja dan cara mengatasinya}

Berdasarkan pengamatan yang penulis lakukan pada saat Prakti Industri di PT. Macanan Jaya Cemerlang khususnya dibagian pra cetak, cetak, dan pasca cetak. Penulis melihat adanya kekurangan dalam penerapan ergonomic kerja, kekurangan tersebut yaitu sebagai berikut:

Masih ada beberapa karyawan yang tidak menggunakan Alat Pelindung Diri (APD) secara lengkap, padahal perusahaan sudah menyedian APD tersebut secara lengkap.

Penyelesaiannya perlu ditekankan atau diberi penjelasaan kepada karyawan tentang pentingnya menggunakan Alat Pelindung Diri (APD) secara lengkap dan sesuai dengan ketentuan itu sangat penting untuk kesehatan dan keselamatan diri sendiri, karena dapat meminimalisir adanya Penyakit Akibat Kerja (PAK). Atau perlu lebih banyak lagi diadakan pelatihan-pelatihan tentang bahaya apabila tidak menggunakan Alat Pelindung Diri (APD) dengan benar dan lengkap, dengan menampilkan gambar-gambar dari akibat tidak menggunakan APD secara benar dan lengkap

Jadwal lembur yang tidak menentu dan diwajibkan bagi karyawan yang kedapatan jadwal lembur, yang menyebabkan karyawan menurun produktivitas kerjanya apabila tidak siap untuk lembur.

Penyelesaiannya harus lebih menghargai hak-hak karyawan, demi kesehatan dan keselamatan kerja karyawan, agar tetap terjaganya produktivitas kerja karyawan.

Kurangnya kotak Pertolongan Pertama Pada Kecelakaan (P3K) dibagian cetak sheet dan web, yang menyebabkan isi kotak P3K sering tidak lengkap karena karyawan yang menggunakannya banyak dan kotak P3K nya yang minim. Hal ini membuat kurang efisien kerja dari karyawan yang 
membutuhkan obat tetapi isi kotak P3K nya sudah tidak lengkap.

Penyelesaiannya perlu adanya penambahan jumlah kotak Pertolongan Pertama Pada Kecelakaan (P3K), agar kebutuhan obat untuk karyawan selalu sedia, dan lengkap. Agar tetap efisiennya pekerjaan karyawan.

Kurangnya rambu-rambu tentang pentingnya pemakaian Alat Pelindung Diri (APD) ditempat kerja karyawan.

Penyelesaiannya memasang ramburambu pemakaian Alat Pelindung Diri (APD) ditempat kerja untuk mengingatkan para karyawan akan pentingnya APD tersebut, dan bila perlu memasang rambu-rambu dampak dari tidak menggunakan APD dengan benar dan lengkap, agar karyawan memahami setiap waktu dampak dari tidak menggunakan APD dan membuat karyawan selalu menggunakan APD nya.

Kurang memperhatikan fasilitas kursi dan meja yang nyaman dan leluasa

Penyelesaiannya perlu adanya kursi yang beralaskan bahan yang lunak seperti kapuk/matras, dll agar karyawan lebih nyaman duduknya, dan perlu adanya meja kerja yang lebih besar ukurannya agar gerak kerja karyawan menjadi leluasa.

Kurangnya alat bantu pada bagian sortir khususnya alat untuk melipat manual, alat bantu lipat pada bagian sortir masih menggunakan alat yang seadanya seperti botol minyak wangi, botol deodorant, dll. Penyelesaiannya perlu disediakannya alat bantu lipat yang benar, seperti tulang pelipat.

Tidak adanya perawatan mesin secara berkala, yang membuat terhambatnya proses produksi apabila ada mesin yang mengalami kerusakan. Penyelesaiannya perlu adanya perawatan mesin secara berkala agar proses produksi tetap lancer, dan agar mesin tidak cepat mengalami kerusakan.

\section{Penerapan Alat Pelindung Diri (APD)}

\section{Bagian Pra Cetak}

Penyediaan Alat Pelindung Diri di bagian pra cetak, dimana penggunaan APD dibagian pra cetak sifatnya wajib untuk digunakan saat para pekerja diarea kerja, dengan tujuan agar keselamatan dan kesehatan para pekerja selalu terjaga dengan baik, dan untuk menghindari adanya Penyakit Akibat Kerja (PAK). APD yang digunakan di bagian pra cetak berupa masker, wearpack, sarung tangan, dan sarung tangan anti panas.

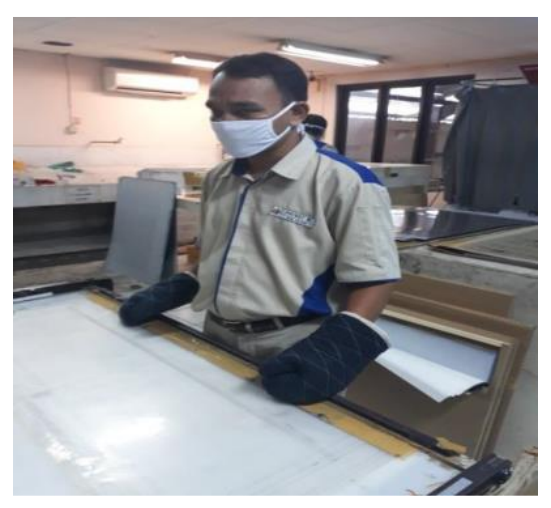

Gambar 4. APD Pra cetak

Kelengkapan Alat Pelindung Diri (APD) di bagian Cetak 
Penyediaan Alat Pelindung Diri di bagian cetak, dimana penggunaan APD dibagian cetak sifatnya wajib untuk digunakan saat para pekerja diarea kerja, dengan tujuan agar keselamatan dan kesehatan para pekerja selalu terjaga dengan baik, dan untuk menghindari adanya Penyakit Akibat Kerja (PAK). APD yang digunakan di bagian cetak berupa masker, wearpack, sarung tangan, dan ear plug untuk bagian cetak web, karena di bagian cetak web suara mesin cetaknya lebih bising dibandingkan suara mesin cetak sheet.

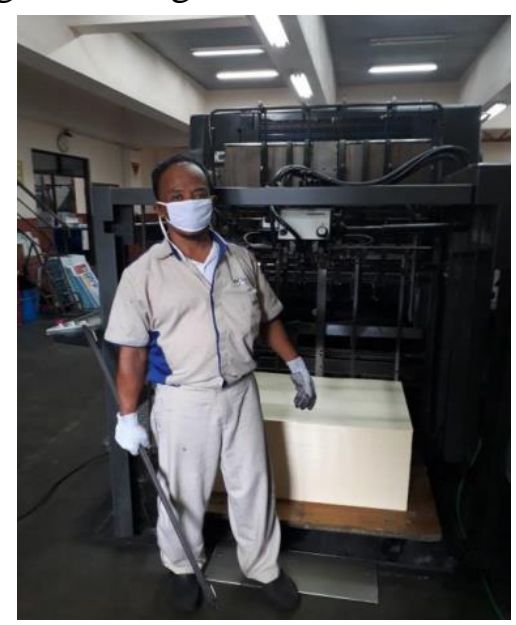

Gambar 5. APD Bagian Cetak Offset

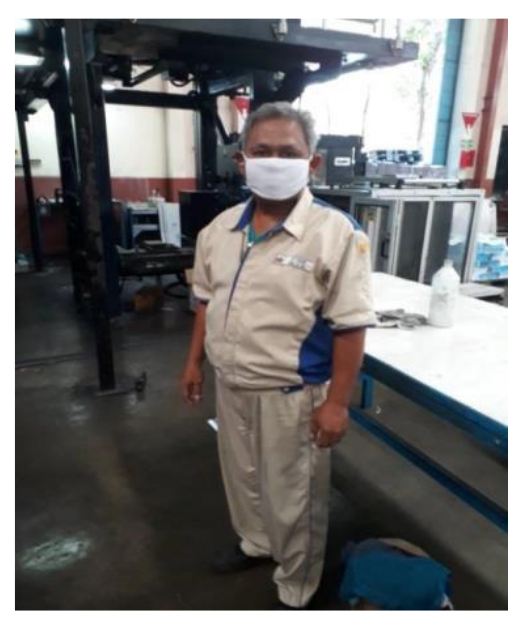

Gambar 6. APD Bagian Cetak Web
Kelengkapan Alat Pelindung Diri (APD) di

\section{bagian Pasca Cetak}

Penyediaan Alat Pelindung Diri di bagian cetak, dimana penggunaan APD dibagian pasca cetak sifatnya wajib untuk digunakan saat para pekerja diarea kerja, dengan tujuan agar keselamatan dan kesehatan para pekerja selalu terjaga dengan baik, dan untuk menghindari adanya Penyakit Akibat Kerja (PAK). APD yang digunakan di bagian pasca cetak berupa masker, wearpack, sarung tangan, dan sarung tangan anti panas untuk bagian perfect binding.

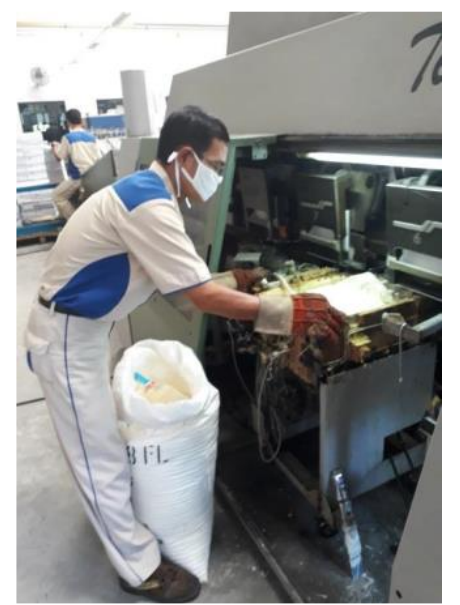

Gambar 7. APD Bagian Pasca Cetak

APD sebagai pengendalian terakhir dari hirarki pengendalian harus tetap diperhatikan setiap bagian termasuk dalam pasca cetak.

Sumber bahaya setiap bagian dalam alur grafika berbeda-beda oleh karena itu APD yang digunakan pun juga akan berbeda. Dengan demikian identifikasi bahaya dan risiko di tempat kerja sangatlah penting 
dilakukan sehingga pencegahan akan lebih efektif dan efisien.

\section{KESIMPULAN}

Berdasarkan pengamatan penulis mengenai penerapan Ergonomi kerja yang berkaitan dengan keselamatan dan kesehatan di PT. Macanan Jaya Cemerlang, maka penulis dapat mengambil kesimpulan berdasarkan data-data yang telah didapatkan adalah sebagai berikut:

Penerapan ergonomi kerja di PT. Macanan Jaya Cemerlang sudah baik, hal itu karena karyawan di PT. Macanan Jaya Cemerlang masuk kerja selalu tepat waktu, mematuhi segala peraturan yang ada, kinerja karyawan yang produktif dan efisien, kesadaran dalam menjaga kebersihan diri sendiri, lingkungan kerja, dan mesin sudah baik.

Program tambahan seperti senam dan jalan sehat, dan pemberian susu sapi murni setelah jalan sehat/senam juga menjadi faktor dalam penerapan ergonomi kerja, karena bisa menjaga kesehatan dan kebugaran karyawan pada saat bekerja. Fasilitas dan alat bantu kerja karyawan juga sudah baik dan lengkap, hanya dibagian sortir yang tidak adanya alat bantu yang sesuai.

Kelengkapan Alat Pelindung Diri (APD) di bagian pra cetak, cetak, dan pasca cetak yaitu masker, sepatu pelindung, ear plug, sarung tangan, dan baju kerja sudah diterapkan dengan baik, kesadaran karyawan dalam menggunakan APD secara lengkap juga sudah baik, namun masih ada beberapa karyawan yang belum menggunakan APD secara lengkap.

Masih kurangnya kotak Pertolongan Pertama Pada Kecelakaan (P3K) yang mengakibatkan isi kotak P3K cepat tidak lengkapnya, karena karyawan yang menggunakannya cukup banyak. Di PT. Macanan Jaya Cemerlang belum adanya perawatan mesin secara berkala yang mengakibatkan terhambatnya proses produksi apabila ada kerusakan pada mesin.

\section{Saran}

Berdasarkan pengamatan yang telah dilakukan penulis mengenai penerapan ergonomi kerja yang berkaitan dengan keselamatan dan kesehatan di PT. Macanan Jaya Cemerlang, maka penulis memberikan saran-saran yang diharapkan dapat berguna bagi perusahaan kedepannya, saran-saran tersebut yaitu sebagai berikut:

Melihat masih adanya beberapa karyawan yang tidak menggunakan Alat Pelindung Diri (APD) dengan benar dan lengkap, sebaiknya dipasang rambu-rambu dampak dari tidak menggunakan APD dengan benar dan lengkap. Rambu-rambu tersebut bisa berupa tulisan atau bahkan disertai gambar sehingga membuat para karyawan mengetahui apa saja dampak dari tidak menggunakan APD dan diharapkan 
rambu-rambu tersebut menjadi pengingat setiap saat yang membuat karyawan enggan untuk tidak menggunakan APD.

Para karyawan diberikan motivasi dan pelatihan tentang pentingnya menggunakan APD dengan benar dan lengkap, agar kesadaran karyawan semakin meningkat.

Perlu penambahan kotak Pertolongan Pertama Pada Kecelakaan (P3K) agar kebutuhan obat-obat untuk karyawan selalu terpenuhi, agar selalu siap untuk melakukan pertolongan pertama apabila karyawan ada yang terkena Penyakit Akibat Kerja (PAK).

Perlu diadakannya perawatan mesin secara berkala, tujuannya agar meminimalisir adanya keruskan mesin, agar proses ptoduksi lebih produktif dan efisien.

Lebih memperhatikan hak-hak karyawan dalam menuntukan jadwal lembur, agar tidak adanya keluhan dari karyawan yang tidak siap unntuk lembur tetapi diwajibkan untuk lembur, dan agar kinerja karyawan tetap produktif.

Menyediakan kursi dan meja kerja dibagian sortir yang lebih nyaman dan luas agar karyawan tidak mengalami pegal dan agar seluruh karyawan psosisi kerjanya benar dan sesuai.

\section{REFERENSI}

Angela, Tinjauan Penerapan Sistem Keselamatan dan Kesehatan Kerja (K3) Pada Bagian Cetak di PT. Pura Barutama Unit Ofset, Politeknik negeri media kreatif, tahun 2016.

Data Hasil Praktik Industri Di PT. Macanan Jaya Cemerlang.

Keselamatankerja.blogspot.co.id pengertian (definisi) K3 (Keselamatan dan Kesehatan Kerja),

Newssefety.blogspot.co.id, informasi kesehatan dan keselamatan kerja, 